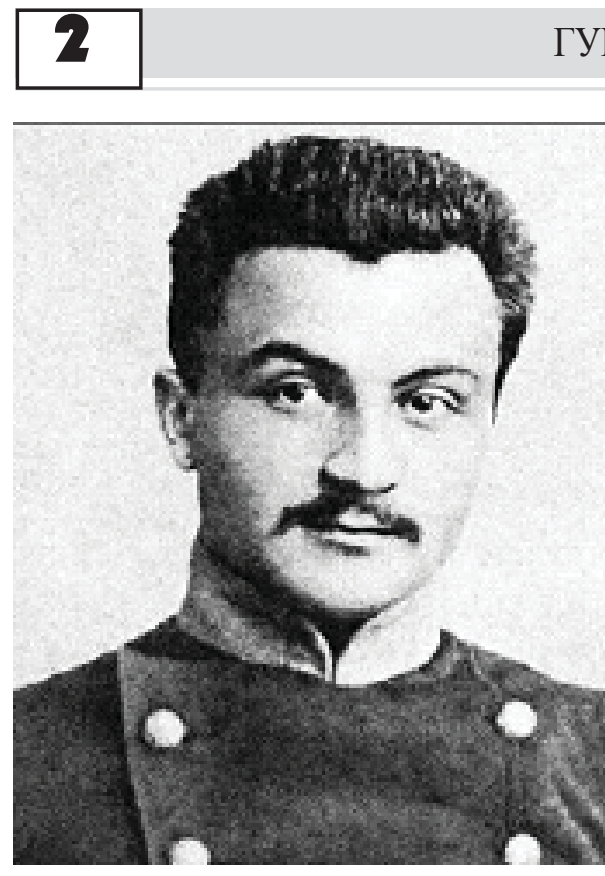

ГУМАНИТАРНЫЙ ХРОНОГРАФ

Ахмед Тембулатович ЦАЛИКОВ (осет. Цæлыккаты Ахмæm; 1882 год, аул Ногкау, Терская область - 2 сентября 1928 года, Варшава, Польша) - осетинский писатель и публицист, российский революционный, государственный и общественный деятель.

Один из лидеров фракции меньшевиков в РСДРП. Сторонник культурной автономии мусульман в составе России. Председатель меджлиса горских народов Кавказа в Тифрлисе. Взгляды Цаликова подвергались критике В.И. Лениным.

После победы Советской власти в Грузии (фревраль 1921) Ахмед Цаликов эмигрировал в Чехословакию, где редактировал журнал «Кавказский горец», затем - в Польшу.

Цаликов известен как автор ряда работ по истории Кавказа, статей, очерков, прозаччских миниатюр и романа «Брат на браma» (Прага, 1926).

Предлагаем вниманию читателя первую часть очерка А.Т. Цаликова "Искоренение грабежей и разбоев на Северном Кавказе» (1913), в котором автор четко поставил один из насущных вопросов общественной жизни Кавказа, показал несостоятельность мер, практикуемых на этом направлении царской администрациeŭ.

DOI 10.23671/VNC.2018.4.23782

\title{
ИСКОРЕНЕНИЕ ГРАБЕЖЕЙ И РАЗБОЕВ НА СЕВЕРНОМ КАВКАЗЕ (фрагмент)
}

\section{А.Т. Цаликов}

Вопрос об искоренении грабежей и разбоев на С. Кавказе неоднократно обращал на себя внимание представителей правительственной власти этой окраины, но принимаемые до сего мероприятия совершенно не достигали цели.

Суровые репрессии в виде экзекуций, постоев казаков в аулах, штрафов, высылки так наз. порочных членов неоднократно обрушивались на головы туземного населения, но указанное зло не только не искоренялось, но с течением времени принимало еще более острый и значительный характер.

Обрушиваясь всей тяжестью главным образом на мирных жителей, разоряя и без того скудное хозяйство горца, эти мероприятия вели только к тому, что увеличивали еще значительнее количество лиц, которым уже больше было терять нечего и которые легко покидали свои очаги и выходили на большую дорогу в качестве профессиональных грабителей.

Всякого рода административные мероприятия в виде билетов, караулов, запрещения иметь хуторянам и овцеводам в качестве объездчиков, приказчиков, сторожейтуземцев, выселение туземцев с левого берега Терека, создание смешанных и примирительных судов и т. д., все эти средства являлись и являются или вредными для искоренения так называемой преступности горцев, или просто недействительными.

Недуг имеет глубокий характер и ни в коем случае не может быть излеченным административной рецептурой. Должны быть оздоровлены источники заразы, а эти источники гнездятся в административно-правовом быте, экономических и культурно-общественных условиях жизни горцев.

Но возвыситься до такого глубокого понимания сущно- сти явления краевая администрация не может. Она блуждает по поверхности и находит единоспасающую меру в принципе: «тащить и не пущать», «загонять куда Макар телят не гонял», «гнуть в бараний рог», «обуздывать и пресекать» и т. д.

Что это именно так, можно видеть хотя 6 из ниже- следующего документа, дающего ясное представление о том, каковы взгляды, напр., Терской администрации на развитие преступности среди горцев и каковыми средствами эту преступность администрация предполагает ослабить: «1903 года сент. 30-го дня, гор. Владикавказ.

Ввиду письма командующего войсками Кавказского военного округа от 20-го того же сентября за № 3208 для обсуждения причин увеличения за последнее время числа разбоев, грабежей и вообще преступлений против личной и имущественной безопасности и для изыскания мер к их прекращению, но в пределах власти начальника области и командующего войсками была образована комиссия под председательством генерал-лейтенанта Толстова в составе старшего и младшего помощников начальника области генерал-майоров Коцебу-Пилара и Писарева, атамана Сунженского отдела генерал-майора Суровецкого, начальников округов: Хасав-Юртовского, полковника барона Угнера; Грозненского, подполковника Попова, и. д. Начальника Владикавказского Округа коллежского советника Василихина, владикавказского полицмейстера подполковника Котляревского, управляющего Областной чертежной действ. стат. совет. Попова, при делопроизводителе канцелярии подъесауле Дикове.

Открывая заседание, г.-л. Толстов прочитал упомянутое письмо командующего войсками и просил каждого из членов высказать свое мнение о причинах усиления преступлений за последнее время и мерах, в пределах власти начальника обл. и командующего войсками, которые 
желательно было бы принять теперь же к их уничтожению или хотя б сокращению.

Резюмируя высказанное на совещании, причинами усиления упомянутых преступлений должно считать:

1. Отмену временного положения 30 сентября 1894 г. об удержании туземного населения от хищничества и всяких насилий против лиц нетуземного происхождения.

2. Большое число абреков, расселенных по области.

3. Влияние агитаторов из Турции, усиленное появление которых особенно стало заметно в последнее время как в Сунженском отделе, так и в Грозненском округе.

4. Неприменение в последнее время закона от 19 ноября 1893 г. о ссылке ското-конокрадов.

5. Легкость приобретения партий усовершенствованного оружия в пределах России и усиленная доставка его в область лицами неблагонадежными и не имеющими права на торговлю оружием, а также заметное усиленное стремление туземцев добывать усовершенствованное оружие путем преступлений.

6. Нежелательный исход дел по оскорблению Начальника 1-го участка Владикавказского округа капитана Степанова, по убийству начальника 2-го участка того же округа капитана Высоцкого, что, несомненно, повлияло на впечатлительное туземное население и отразилось повышением числа неповиновений и сопротивлений административной власти.

По мнению большинства членов число преступлений за последнее время не увеличилось, а таковые стали только более дерзкими.

Из числа мер, коими возможно в некоторой степени ослабить число преступлений, намечены:

1. Иметь в разных местах области сыщиков (!), хотя б в таком числе и в тех пунктах, как об этом просилось начальником области в отзыве в Главное Управление Казачьих войск от 1902 г., так как, принимая во внимание поголовное укрывательство преступников в туземной среде, администрация почти бессильна раскрывать преступления.

2. Ввести в области институт урядников.

3. Ходатайствовать о скорейшем упразднении Терской постоянной милиции, ввиду полной ее ненадежности, с заменой ее Терской постоянной стражей, на службу в которую, благодаря улучшенному материальному положению, будет идти более благонадежный элемент.

4. Улучшить материальное положение сельских старшин, дабы иметь в лице их более надежных представителей русской власти и более дорожащих своею службой, так как только этим путем и можно привлечь к занятию этих должностей людей более или менее нравственных, пользующихся уважением населения.

5. Предание военному суду применять возможно чаще - во всех случаях вооруженного грабежа и разбоя и при сопротивлении властям.

6. Ссылку на остров Чечен применять также в более широких размерах, так как туземцы боятся этого более, чем ссылки в Сибирь.

7. Принять меры к предупреждению ввоза в пределы области партий оружия путем подлежащего сношения с железнодорожной жандармскою полицией о досмотре подозрительных товаров и товарных грузов.

8. В экстренных случаях предоставить право начальникам округов и атаманам отделов выставлять жительские караулы по дорогам, но чтобы это тотчас же доносилось на утверждение начальника области.

9. Исходатайствовать разрешение пользоваться для поимки и преследования преступников командами разведчиков и охотников строевых частей, расположенных в области.

10. Исходатайствовать право пользоваться войсками для прикрытия и при обысках в селениях, по соглашению с начальником гарнизона, испрашивая на это разрешение командующего войсками - шифрованными депешами, а не особыми мотивированными представлениями.

11. Просить о распространении на Терскую область: «общих указаний войскам и гражданским властям при совместных действиях по охране спокойствия и в борьбе с разбойниками в Кавказском крае на 1899 г.», утвержденных Главноначальствующим и командующим войсками 25 февраля 1899 г.

12. Пользоваться возможно шире законом 19 ноября 1893 г. по точному его смыслу, не ограничивая применений его только к лицам, имеющим несколько недавних судимостей (не менее двух), а и на всех порочных лиц, хотя б и оправданных по суду по обвинению в ското- и конокрадстве, так как большей подозрительности, как предание суду, трудно отыскать.

13. Принять меры к обнаружению и задержанию турецких эмиссаров для водворения их обратно в Турцию.

14. Изложенное п.п. 1, 2 и 3 не во власти Командующего войсками округа».

Из приведенного документа видно, как поверхностно смотрят административные власти на то зло, которое приняло угрожающие размеры.

Ни причины развития грабежей и разбоя не получили должного освещения, ни тем более не указаны действительные средства к искоренению или даже некоторому ослаблению зла.

Кругозор лиц, разрабатывавших такой важный краевой вопрос, оказался безгранично узким.

Мы не говорим уже о соображениях вроде пункта 3 , об «агитаторах из Турции», соображениях, достойных гоголевских персонажей, которые также глубокомысленно старались увидеть козни «англичанки» в тех или иных проявлениях внутренней жизни страны.

Усиление репрессий, военные суды, ссылки на остров Чечен, штрафы и т. п. - вот единственные средства из кладовой административной мудрости.

А зло «все растет и растет, все на витязей с боем идет».

Мы не будем давать исторического обзора всех репрессий, обрушивавшихся на головы туземцев, якобы с целью искоренения среди них преступности, скажем только одно, что все меры, предпринимавшиеся администрацией, не только не достигали цели, но наоборот - они экономически разоряли туземцев, нравственно их деморализировали и вели к вящему развитию преступных наклонностей.

Убивалось систематически нравственное достоинство, оскорблялись святыни, развивали подхалимство, человекоугодничество, раболепие, натравливали брата на брата, пробуждали корыстолюбие.

Можно еще удивляться, как при всех неблагоприятных условиях горцы сохранили в глубине своей натуры массу первобытного благородства и нравственной чистоты.

А кажется, что принимались все меры к тому, чтобы убить в них эти качества, вооружить их друг против друга и сделать край ареной еще неслыханных кровавых междоусобиц. 